\title{
Impact of Credit Market Development on Project Financing
}

\author{
Monika Poradova ${ }^{1, *}$ and Katarina Janoskova ${ }^{1}$ \\ ${ }^{1}$ University of Žilina in Žilina, Faculty of Operation and Economics of Transport and \\ Communications, Department of Economics, Žilina, Slovakia
}

\begin{abstract}
The purpose of our report is to assess the prospects and sentiment for bank financing in the real estate sector in Europe, based on the views of bank representatives from 15 European countries. The presented paper is devoted to the issue of project financing. The aim is to provide an analytical overview of the issue of project financing as a specific credit financing instrument with the current access to finance for banks in Europe. The paper consists of four parts. The first part deals with the issue of project financing, the different dates of project financing and classifies project financing in terms of penalties. The second part of the paper aims to clarify the alternative method of project financing and analysis of banks in Europe. The third part of the article addressed the concrete results of the analysis and carried out discussion. Describes the volumes of credit transactions. The fourth part deals with the conclusion of the issue of project financing. A descriptive method, analysis, mathematical-statistical methods, graphic methods, comparison and synthesis was used in the processing of the paper submitted. The result of this article is that, in the future, the general financing conditions are expected to remain relatively favourable across Europe. This may be due in particular to competitive pressure contributing to milder credit conditions. However, trade tensions, declining investments, as well as policy concerns on a global scale, may curb such optimism for the next few years.
\end{abstract}

Keywords: project financing, banks, credit financing, investment project

\section{Introduction}

The first mentions of project financing have been recorded since the thirteenth century. Of course, this method of financing has undergone considerable development over several centuries and has been transformed into the form we know it today. In the twentieth century, project financing has seen significant expansion, particularly in America and Europe. Today, we can also meet with him in developing countries, where he has his justification for building infrastructure and development as a whole. Project financing is a form or also a technique by which we can finance a project. In practice, there are many types of projects where the form of project financing is applied. From the implementation

*Corresponding author: monika.poradova@fpedas.uniza.sk 
of industrial projects, infrastructure development, energy, water management, real estate construction to internationally significant projects. [1]

Project financing is a specific form of financing which has some differences from other loans. Obtaining a loan is preceded by the creation of a separate economic unit specifically for a specific project. An interesting feature is the form of repayment of the credit, which is based on the flows that the project produces after its completion in the operation itself. [2] The implementation of large-scale projects requires close cooperation between several entities. The success of the whole project is conditional on the preparation detailed project, technical documentation, selection of right entities to participate in the project.

The growing interest in this form of funding has prompted authors, economists to dedicate and explore project financing. In publications, we may encounter several definitions of the concept of project financing, but by its very nature, we class it as part of investment banking. [3]

Project financing as individual financing of an economic unit, which first takes into account the future earnings and cash flow of the project from which the credit will be repaid. [4] Another definition refers to a legally independent project. It emphasises that the repayment of the credit is directly conditional on the fund's real institutions of the economic unit. Project financing involves the creation of a legally and economically independent project company, which is financed in a non-recourse manner, usually with a fixed maturity. Lenders and sponsors will view the economic unit as a single cash flow generator and a source of security and credit repayment. Creditors have no or limited penalty against the sponsor. [5]

Project financing is characterised by the separation of project financing from other business activities of the investment firm. The granting and repayment of the credit are closely linked to the cash flows of the project both at the construction stage and in its subsequent operation. The subject of financing is a large-scale long-term investment project, where the loan repayment scheme is derived from the project's planned revenues. At the forefront of the interest is the elimination of the risk of the creditor in the phase of construction of the project and implementation of the investment plan. [6]

Project financing is mainly linked to forecasting the effect of the selected project and relies only to a small extent on the company's own resources. The starting point is the existence of a large-scale investment project with a detailed project and financial documentation. With a special technical and financial-economic evaluation of the project by an independent expert. Separating project financing from other activities of the company will ensure the establishment of a special project company, which will focus all resources on the project envisaged. [7]

Bartosova, Kral talks in its publication about the common features of project financing and syndicated credit. Although project financing is essentially characterised by certain specificities, it advises it into a sub-group of syndicated loans. There is no exact line between project financing and other types of funding where a large amount of funding is needed to finance a project. Ultimately, we can categorize project financing as a form of structured financing falling within the subject of investment banking. [8]

\subsection{Types of project financing}

Project financing is individually tailored to the specific needs of the project. Efficiency is linked to the cash flow of the project and the total assets of the project. Risks are divided between shareholders and investors. Another criterion for a successful project is its ability to function independently as a legal and economic entity. [9] In project financing, we distinguish two different types, which differ from each other in the different application of recourse to investors in a given project. The essence of project financing lies in the fact that 
it is not possible to apply a full sanction to project investors, but only a limited sanction. Project funding without non-recourse and limited recourse are therefore one of the key factors underlying project funding.

\subsubsection{Non-limited recourse project financing}

Non-limited recourse project financing is a relationship between entities where project creditors and investors have no sanction on the project sponsor's assets. Non-retrospective financing, therefore, depends purely on the project's ability to generate cash flow as well as on the creditworthiness of the project sponsor. [10] Repayment of credit and liabilities, therefore, places the greatest emphasis on the project's projected cash flow, which serves as a source of repayment. Repayment of the credit is independent of the creditworthiness of the project sponsors. In this case, the project sponsor has no direct legal obligation to repay the project debt or interest payments. This type of project financing is relatively unique because it carries potential risks. [11]

\subsubsection{Limited-recourse project financing}

In most cases of project financing, the obligations and responsibilities of the project sponsor are limited, meaning that it is project financing with limited-recourse finance. [12] It provides creditors and investors with a certain recourse against project sponsors. In this case, the creditors are therefore entitled to demand repayment from the sponsor only in part or only at certain stages of the project. It can be said that the project sponsors undertake to end the project in the event of failure. The sponsors of the project are therefore persons who invest the share capital in a special entity. An important measure for 16 successful completion is to design the project documentation so that it can respond flexibly to unwanted changes that may occur. Nevertheless, investors are primarily focused on the success of the project. This second type of project financing is generally more widely used, especially in market developing countries.

The number of recourses needed to support funding depends on the unique characteristics of the project and its complexity. The large impact on the risk and the overall risk profile of a particular project depends on the extent of the aid to the investor. [13] The forms and methods of recourse can, of course, be the subject of negotiations between the bank, the creditor and the investor.

\section{Methodology}

Project financing is a progressive specific technique of credit financing of investmentintensive projects, which began to be applied especially in the 70 s of the last century. Using this technique, it is possible to accumulate financial resources in a sufficient amount to finance infrastructure projects and at the same time redistribute investment and project risk among the participants. In developed economies, it is currently a common way of financing investment-intensive infrastructure and other projects.

\subsection{Bank analysis}

The banking sector has undergone many structural changes since the 1990s, which were necessary for its stability and efficient performance. In the mid-1990s, at the time of privatization, the banking sector was in a bad state in most countries and threatened to collapse the entire system and capital markets. Undercapitalization, low liquidity led to 
remedial measures and restructuring of the entire banking system. Project financing, which belongs to the investment banking portfolio, represents a dynamically developing form of financing. [14]

The aim is to provide an analytical overview of the issue of project financing as a specific credit financing instrument with the current access to finance for banks in Europe. As part of specific globalization processes, capital is not only focused on local markets but is moving to different parts of the world. Project financing is mainly associated with the financing of construction projects, but the possibilities of using this product are much wider. All the largest banks were involved in project financing. The analysed banks are mainly involved in financing projects in the area of:

- Real Estate: construction of apartment houses, administrative projects, industrial halls, logistics centres, hospitality, shopping and entertainment centres, sports parks,

- Energy projects: renewable energy sources, photovoltaic power plants, wind power plants, biomass heating plants,

- Municipal projects,

- Transport projects,

- $\quad$ Projects supported by EU funds. [15]

Depending on the survey participants' organisational structure, interviewees were the heads of real estate, project financing or risk management departments. Banks were selected from among the leading financial institutions operating in each individual country. The majority the survey participant banks were local, i.e. those operating predominantly within one European country, whilst the rest were mainly regional banks, as well some multinational banks participated.

The paper includes input from close to 70 banks, collected primarily via in-depth interviews and online questionnaires. Representatives from leading financial institutions have provided their views on the key issues influencing property lending. The questionnaire survey was conducted for the whole year 2019. The first half of 2020 the questionnaire survey was evaluated. The following countries are represented in the 2019 survey: Bulgaria, Croatia, the Czech Republic, Cyprus, Finland, Germany, Greece, Hungary, Ireland, the Netherlands, Poland, Romania, Serbia, Slovakia and Slovenia. The banks were selected from the leading financial companies of the institution operating in each individual country.

Selected countries were compared on the basis of geographical locations and two categories of analysis were created. The first is the "Economies of Central and Eastern Europe". These countries are located in Central and Eastern Europe, including most of the Balkans. Due to their geographical proximity and the relatively comparable stage of economic and development of these countries, they are assumed to be similar mainly due to their advantages and challenges. Therefore, the created group of countries consists of Bulgaria, the Czech Republic, Hungary, Poland, Slovakia, Romania.

Unlike Central and Eastern Europe, other European countries form the second category: "Other European Economies". Precisely because of their different economic capabilities, they provide a benchmark for evaluating data from Central and Eastern Europe. This category includes: Cyprus, Finland, the Netherlands, Ireland and Greece. In figure 1 is a geographical representation of the banks of the countries included in the sample. 


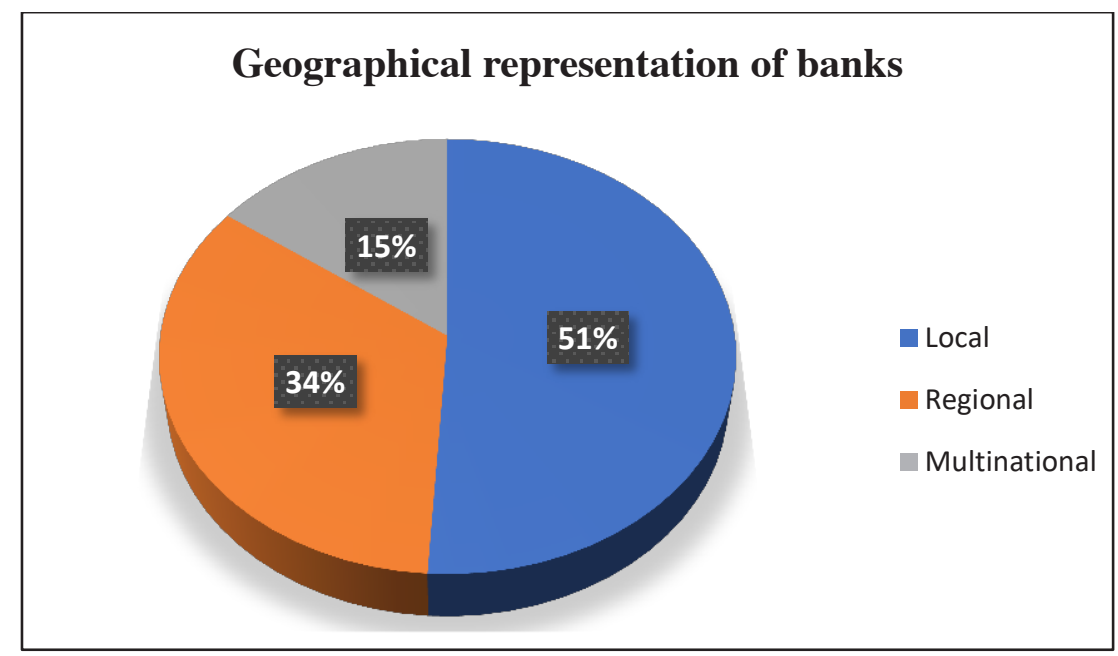

Fig. 1. Geographical representation of banks by countries included in the sample Source: Own processing according to Lending Barometer 2019.

\section{Results and Discussion}

When financing investment plans through project financing, the greatest emphasis is placed on finding the optimal sources of project financing. When obtaining resources, it is most important to make the best use of the resources that are available and to obtain security from external sources as advantageously as possible. Traditionally, in this case, credit from one or more banks are used. Project financing involves obtaining a large amount of funds, so it is most often a combination of several sources. As credit as an external source of project financing is the most important and most frequent alternative for the implementation of such projects, the analysis will be based primarily on credit in selected countries.

First, the breakdown of the volume of credit transactions by individual countries of Central and Eastern Europe in 2018 and 2019 was analysed, which are shown in figure 2. 


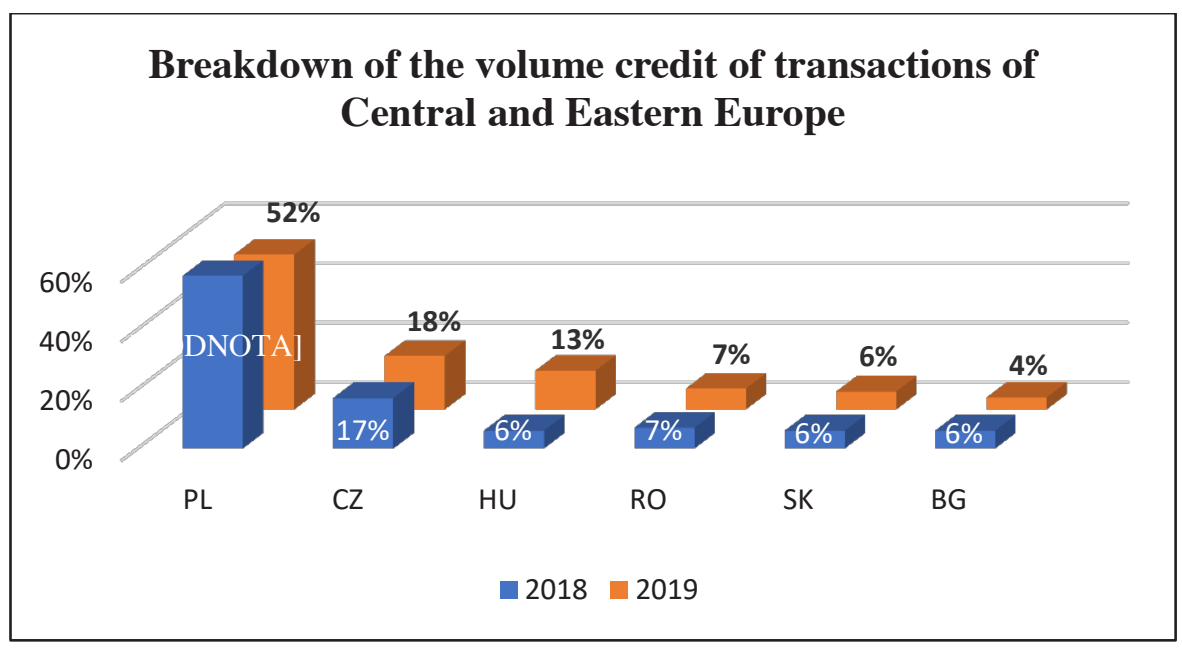

Fig. 2. Credit transaction volume by country of Central and Eastern Europe Source: Own processing according to Lending Barometer 2019.

In the medium-term trend since 2014, the continuing growth of credit activity in Central and Eastern Europe is in almost all credit categories. In 2019, this trend was expected to continue, which proved to be correct assumption. This is mainly due to competitive pressure, which contributes to simpler credit conditions, especially in the larger countries of Eastern and Central Europe. Sustained quantitative easing by the European Central Bank has had a positive effect on many borrowing opportunities in Europe for many years. This was a major factor in improving the forecast for bank credit.

The increased level of activity in the credit portfolio market has maintained its dynamics over the last year. However, pressure on banks to consolidate their balance sheets and sell more of their outstanding credit portfolios remains a key driver of the market. As a result, traders have been closed in the European portfolio market amounting to approximately 50 billion in the first half of 2019.

Based on the analysis of the volume of credit transactions, an analysis was made of the investments that are most often provided through credit in Central and Eastern Europe, which are shown in figure 3. In this analysis, five main categories of credit were identified. These include Office, Retail, Industrial, Hotel and Residential. 


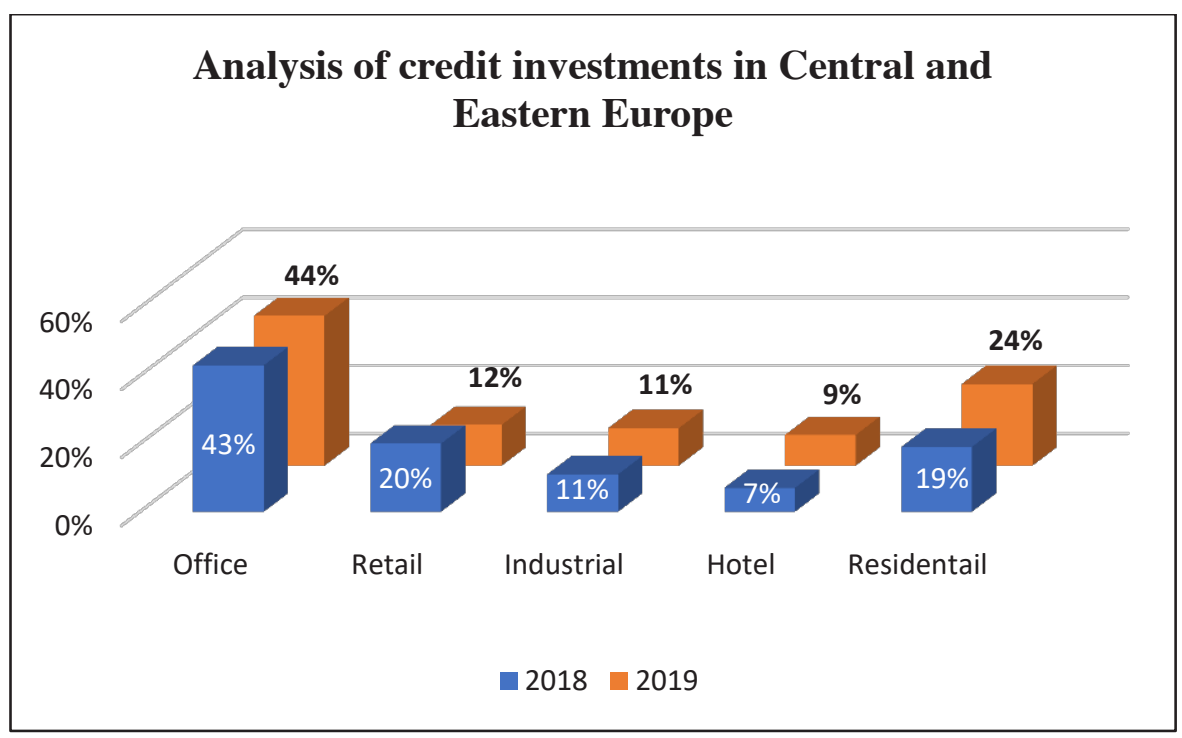

Fig. 3. Analysis of credit investments, which are most often provided through credit in Central and Eastern Europe

Source: Own processing according to Lending Barometer 2019.

In the breakdown of investment in Europe in the Residential sector, there was a remarkable increase in its share last year. Data for 2019 represent that the office sector is still the most important, reaching up to $44 \%$. Subsequently, the retail sector reaches $20 \%$, the industrial sector reaches $11 \%$ and the hotel sector reaches $9 \%$. The retail sector suffered a decline of $51 \%$ compared to the decline in 2018 . On the other hand, the hotel sector grew by $3 \%$.

Sustained quantitative easing by the European Central Bank has had a positive effect on many borrowing opportunities in Europe for many years. This was a major factor in improving the forecast for bank credit.

\subsection{Managing impaired credits}

Banks apply a variety of credit measures to address the global economic crisis, including the restructuring, closing or sale of non-performing credit portfolios. Therefore, in this article, we have assumed that Western European markets are recovering faster and more widely in terms of disadvantaged loans than Eastern and Central Europe. The results of the analysis of the established assumption are shown in Figure no. 4 and 5. Western European markets are recovering faster and more widely in terms of bad credit. 


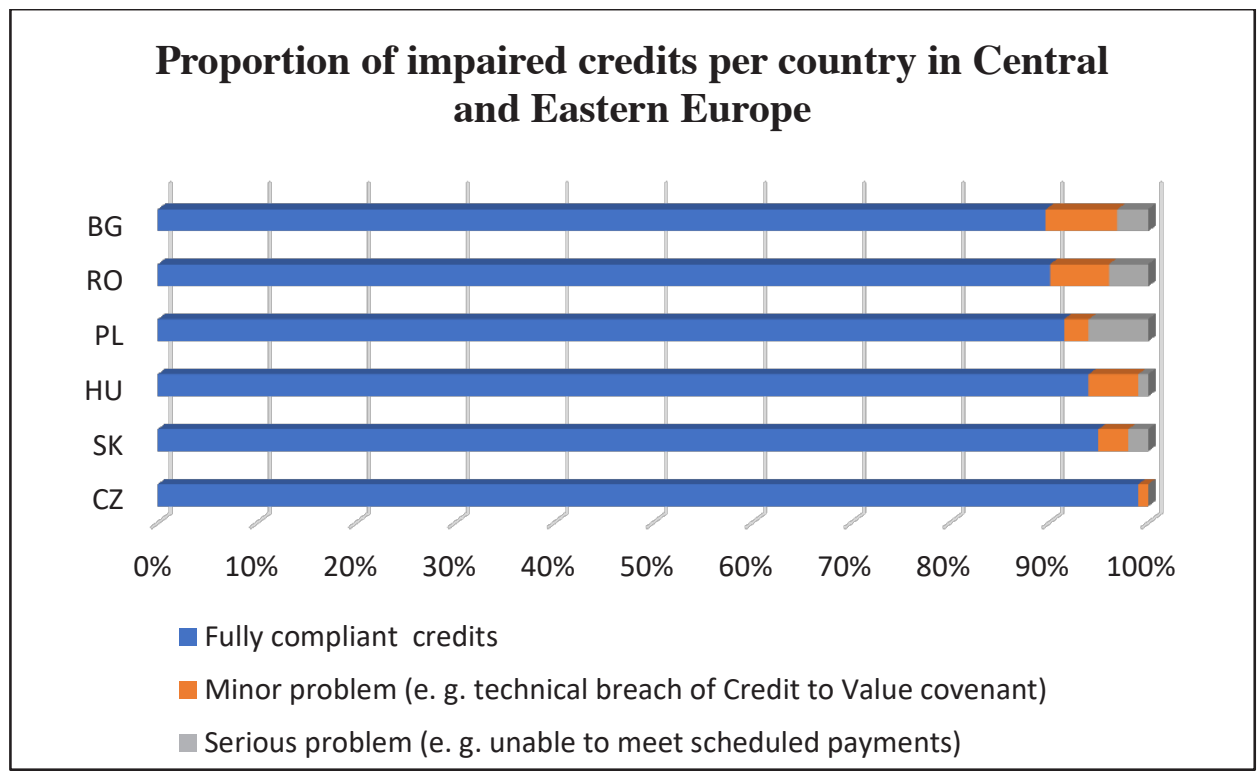

Fig. 4. Proportion of impaired credits per country in Central and Eastern Europe Source: Own processing according to Lending Barometer 2019.

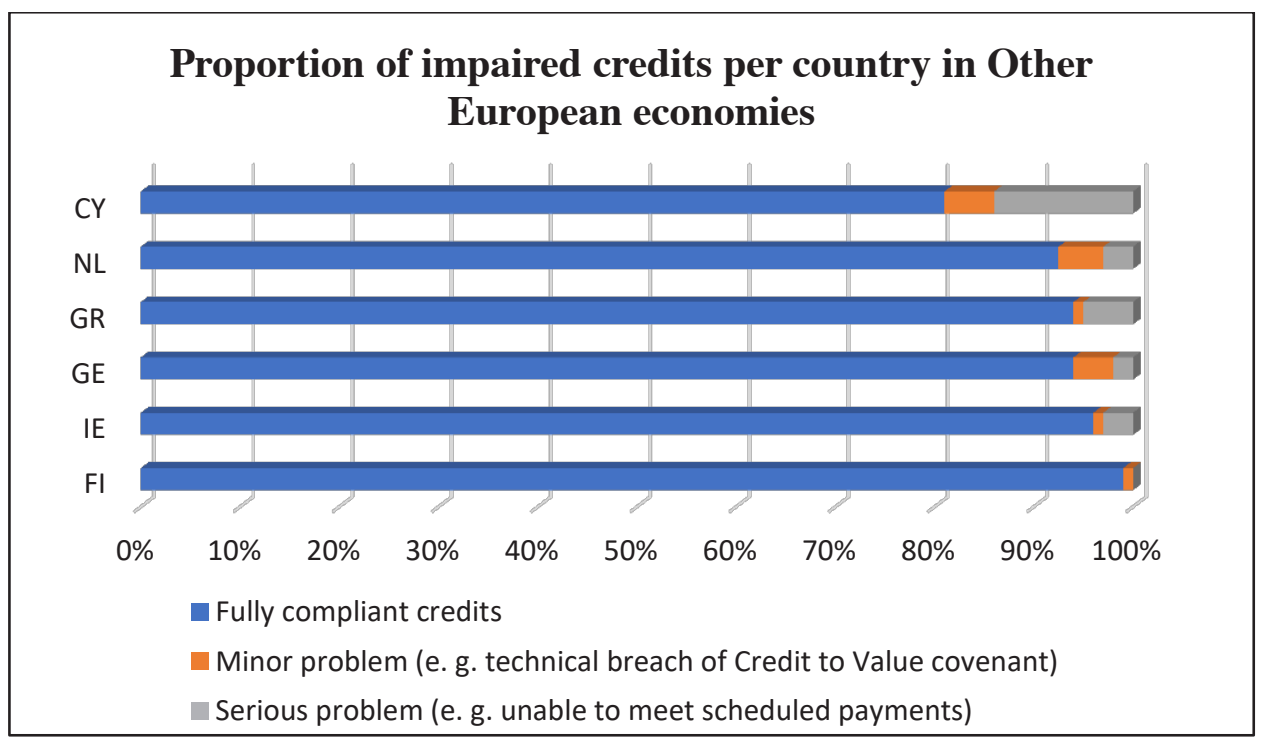

Fig. 5. Proportion of impaired credits per country in Other European economies Source: Own processing according to Lending Barometer 2019.

The share of fully compliant credits is particularly high in Finland and the Czech Republic. With the current rate of fully compliant credits, exceed $99 \%$. While only some countries, such as in our survey with a ratio of less than $90 \%$, represent the country of Bulgaria and Cyprus. Other countries in the survey range on average between 90-98\%.

The analysis of the set assumption confirmed the successful management of impaired loans in all countries, not only in Western European countries.

Project financing offers the creation of a separate economic unit for a specific project. In the case of the concept of non-recourse, the credit is repaid from the cash flow generated 
by a separate economic unit. In this way, the sponsor gets a significant advantage by not guaranteeing the repayment of the credit. In this case, the credit is covered by the project assets. [16] The advantage of project financing is also that the sponsor does not show any liabilities to the project in its balance sheet statement. The form of off-balance-sheet financing does not affect the overall indebtedness of the sponsor. This is especially important when the project is not developing favourably and could have a negative impact on the sponsors' financial profile.

In the event that the ratio of the sponsor's equity to the total resources needed for the project is disproportionate, we speak of a high share of debt. For the lender, this option is acceptable only after a thorough analysis of the entire project, when the project is high quality and viable. Lenders generally require a ratio of $25 \%$ to $55 \%$ of equity to the total resources needed for the project. [17] This requirement is related to the complexity of the project and the expected cash flow that the project will generate. The level of indebtedness in project financing is conditioned by the distribution and limitation of risks. When selecting, the sponsors take into account the risks, the size of the equity, the length of the credit repayment, the capital intensity of the entire project and its profitability. [18] When financing projects, the classic form of credit financing is often used. It is therefore up to the project sponsors what form of funding they will decide on with careful consideration of their options and expectations. [19] One of the main differences between project financing and traditional financing in the form of credit is in the process of the flow of funds that flow into a specific project. In credit financing, the resources provided by the creditor are transferred directly to the sponsor, who finances the project together with its own capital. [20] In the form of project financing, the creditor transfers external resources directly to the project, not through the sponsor.

\section{Conclusion}

This paper provides an overview of the European market as a whole, by focusing on key issues such as the strategic importance of real estate financing for banks, and the proportion of impaired loans. We also consider areas such as banks' average and preferred loan/deal size, as well as the length of loan contract term.

In the future, the general financing conditions are expected to remain relatively favourable across Europe. This may be due in particular to competitive pressure contributing to milder credit conditions. However, trade tensions, declining investments, as well as policy concerns on a global scale, may curb such optimism for the next few years.

When completing the questionnaire, bank representatives also answered the question of what other sectors they considered attractive in terms of financing. Overall, the food and manufacturing industries were selected from the answers, which banks prefer over financing development projects. Banks in general continue to offer more favourable terms when financing income-generating projects than for new developments. Among alternative lenders, respondents say that non-local commercial banks are banks' strongest competitors in most European countries, while private equity/debt funds provide an equally significant competitive threat in the other European economies' country group.

The preparation of project financing is an extremely complex and often costly process that requires a thorough examination of the future development of the project environment and individual solutions. Compared to traditional operating financing, it represents a more expensive way of financing projects, as financial institutions are aware of the increased risk, which is offset by a higher interest margin. Properly functioning project finance can help break down the long-standing barrier between business and financial institutions. Both parties are existentially dependent on each other. This creates a suitable space for closer cooperation and the joint realization of the goals of both parties. Financing through credits - 
it means mostly by foreign sources, is more advantageous in the area of project financing than in the case of financing with own capital. Therefore, project financing has become an important tool in business practice, which is associated with the creation of new opportunities and the implementation of new investments.

The contribution is an output of the project VEGA 1/0619/20 Fundamental research of quantitative and qualitative determinants of enterprise innovation potential and innovation performance in relation to increasing its competitiveness.

\section{References}

1. E. Nica, A. M. Potcovaru, R. E. Hurdubei (Ionescu), Resilient cyber-physical systems and big data architectures in Industry 4.0: smart digital factories, automated production systems, and innovative sustainable business models. Economics, Management, and Financial Markets, 14(2), 46-51 (2019)

2. W. Thierie, L. De Moor, Loan tenor in project finance. International journal of managing projects in business, 12(3), 825-842 (2019)

3. D. Satish, EXIM Bank's Rampal Project Financing Dilemma. Asian case research journal, 23(2), 237 (2019)

4. B. Aimurzina, M. Kamenova, A. Omarova, G. Bodaubayeva, A. Dzhunusova, G. Kabdullina, Major sources of financing investment projects. Entrepreneurship and sustainability issues, 7(2), 1555-1566 (2019)

5. E. Alani, S. Kamarudin, L. Alrubaiee, R. Tavakoli, A model of the relationship between strategic orientation and product innovation under the mediating effect of customer knowledge management. Journal of International Studies, 12(3), 232-242 (2019)

6. V. Oliinyk, O. Kozmenko, I. Wiebe, S. Kozmenko, Optimal control over the process of innovative product diffusion: the case of Sony corporation. Economics and Sociology, 11(3), 265-285 (2018)

7. A. Jakimowicz, D. Rzeczkowski, Do barriers to innovation impact changes in innovation activities of firms during business cycle? The effect of the Polish Green Island. Equilibrium. Quarterly Journal of Economics and Economic Policy, 14(4), 631676 (2019)

8. V. Bartosova, P. Kral, A methodological framework of financial analysis results objectification in the Slovak Republic, Proceedings of the 3rd International Conference on Business and Economics, pp. 189-197 (2016)

9. D. Vrtana, A. Krizanova, Brand Strategy of Successful Companies. Vision 2020: sustainable economic development and application of innovation management, pp. 8007-8014 (2018)

10. P. Bednar, M. Halaskova, Innovation performance and R\&D expenditures in Western European regions: divergence or convergence?. Journal of International Studies, 11(1), 210-224 (2018)

11. E. Geroe, Non-recourse project financing for concentrated solar thermal power. Utilities policy, (2019)

12. P. Durana, K. Valaskova, L. Vagner, S. Zadnanova, I. Podhorska, A. Siekelova, Disclosure of strategic managers' factotum: behavioral incentives of innovative business. International Journal of Financial Studies, 8, 17 (2020) 
13. Y. N. Wang, X. H. Jin, Structural risk of diversified project financing of city investment company in China based on the best worst method. Engineering construction and architectural management, (2019)

14. P. Kral, V. Valjaskova, K. Janoskova, Quantitative approach to project portfolio management: proposal for Slovak companies. Oeconomia Copernicana, 10(4), 797-814 (2019)

15. R. M. Visconti, D. Morea, Healthcare Digitalization and Pay-For-Performance Incentives in Smart Hospital Project Financing. International journal of environmental research and public health, 17(7), (2020)

16. K. Ajaz Khan, G. Çera, V. Nétek, Perception of the selected business environment aspects by service firms. Journal of Tourism and Services, 10(19), 111-127 (2019)

17. G. A. Pazilov, L. A. Bimendiyeva, N. P. Ivashchenko, A. N. Aitymbetova, Textile industry: issues of managing the growth of innovative activity in enterprises. Polish Journal of Management Studies, 21(1), 297-315 (2020)

18. K. Valaskova, V. Bartosova, P. Kubala, Behavioural aspects of the financial decisionmaking. Organizacija, 52(1), 22-32 (2019)

19. K. Valaskova, P. Durana, P. Adamko, J. Jaros, Financial compass for Slovak enterprises: modeling economic stability of agricultural entities. Journal of Risk and Financial Management, 13(5), 92 (2020)

20. J. C. Hollowell, B. Kollar, J. Vrbka, E. Kovalova, Cognitive decision-making algorithms for sustainable manufacturing processes in Industry 4.0: networked, smart, and responsive devices. Economics, Management, and Financial Markets, 14(4), 9-15 (2019)

21. KPMG [online], Available at: https://home.kpmg/xx/en/home.html (2019) 